Konservasi Hayati, 17 (2): 56-62, Oktober (2021)

https://ejournal.unib.ac.id/index.php/hayati/

p-ISSN: 0216-9487

email:konservasihayati@unib.ac.id

e-ISSN: 2722-1113

\title{
SURVEY KETERSEDIAAN PESTISIDA HAYATI DI PROVINSI BENGKULU
}

\author{
Magdalena $^{1)}$, Tunjung Pamekas ${ }^{2)}$, Marwanto ${ }^{3)}$ \\ ${ }^{1}$ Program Studi Agroekoteknologi Fakultas Pertanian Universitas Bengkulu \\ ${ }^{2}$ Program Studi Proteksi Tanaman Fakultas Pertanian Universitas Bengkulu \\ Jl. W.R. Supratman Kandang Limun Bengkulu 38371 \\ * corresponding author: tunjungpamekas@unib.ac.id
}

\begin{abstract}
Biological pesticide is a type of pesticide made from living organisms such as bacteria, fungi, nematodes or viruses that can control or inhibit the growth of pathogens in plants. This study aims to evaluate the availability of biological pesticides in the city and several districts in Bengkulu province. This research method uses a purposive random sampling method, namely by studying the map of the city/district, then a sample of the sub-districts located on the edge of the highway is taken randomly. The survey was conducted in Bengkulu City (Muara Bangkahulu, Teluk Segara, Ratu Agung, Selebar, and Kampung Melayu subdistricts), Central Bengkulu Regency (Karang Tinggi, Pondok Kelapa, and Talang Empat sub-districts), Kepahiang District (Kepahiang, Merigi, and Ujan Mas sub-districts). ), and Rejang Lebong District (Curup, South Curup, Central Curup, and North Curup Districts). The results showed that pesticides/biological products were only available in three regencies and four sub-districts, namely Central Bengkulu District (Talang Empat District: Futrico in powder form and gray in color), Kepahiang (Kepahiang District: Bionsekta in powder form and brick red in color, Kepahiang District: Bionsekta in powder form and brick red in color, Merigi: TAYU's Biological Soil Treatment is liquid and brown in color and has a slightly pungent smell) and Rejang Lebong District (Curup Tengah District: Organic Soil Treatment (OST) Green Botane is granular and black in color). The availability of biological pesticides is very limited so that the use of chemical pesticides remains high.
\end{abstract}

Keywords: Biological pesticides, Province Bengkulu

\begin{abstract}
ABSTRAK
Pestisida hayati adalah salah satu jenis pestisida yang berbahan utama makhluk hidup seperti bakteri, cendawan, nematoda atau virus yang bisa mengendalikan atau menghambat pertumbuhan patogen pada tanaman. Penelitian ini bertujuan untuk mengevaluasi ketersediaan pestisida hayati di Kota dan beberapa Kabupaten di Provinsi Bengkulu. Metode penelitian ini menggunakan metode purposive random sampling, yaitu dengan mempelajari peta kota/kabupaten, kemudian diambil sampel kecamatan yang berada di pinggir jalan raya secara random. Survey dilakukan di Kota Bengkulu (kecamatan Muara Bangkahulu, Teluk Segara, Ratu Agung, Selebar, dan Kampung Melayu), Kabupaten Bengkulu Tengah (Kecamatan Karang Tinggi, Pondok Kelapa, dan Talang Empat), Kabupaten Kepahiang (Kecamatan Kepahiang, Merigi, dan Ujan Mas), dan Kabupaten Rejang Lebong (Kecamatan Curup, Curup Selatan, Curup Tengah, dan Curup Utara). Hasil penelitian menunjukkan bahwa pestisida/produk hayati hanya tersedia di tiga Kabupaten dan empat Kecamatan, yaitu Kabupaten Bengkulu Tengah (Kecamatan Talang Empat: Futricho berbentuk tepung dan berwarna abu-abu), Kepahiang (Kecamatan Kepahiang: Bionsekta berbentuk tepung dan berwarna merah bata, Kecamatan Merigi: Pembenah Tanah Hayati TAYU berbentuk cair dan berwarna coklat serta baunya sedikit menyengat) dan Kabupaten Rejang Lebong (Kecamatan Curup Tengah: Organic Soil Treatment (OST) Green Botane berbentuk butiran dan berwarna hitam). Sangat terbatasnya ketersediaan pestisida hayati sehingga penggunaan pestisida kimia tetap tinggi.
\end{abstract}

Kata Kunci: Pestisida hayati, Provinsi Bengkulu 


\section{PENDAHULUAN}

Pestisida hayati adalah salah satu jenis pestisida yang berbahan utama makhluk hidup seperti bakteri, cendawan, nematoda atau virus. Masyarakat di Provinsi Bengkulu belum banyak mengenal pestisida hayati. Perlu dilakukan survey pada beberapa toko pertanian untuk mengevaluasi ketersediaan persisida hayati di Kota dan beberapa Kabupaten di Bengkulu.

Hasil penelitian (Antonius dan Agustiyani, 2011) menemukan bahwa dengan memberikan campuran berbahan dasar Pseudomonas sp, Bacillus sp, dan Streptomyces sp. dengan 50\% pupuk NPK rekomendasi selain dapat meningkatkan pertumbuhan vegetatif tanaman, juga bisa menambah sifat biokimia tanah dan hasil Citrullus lanatus jika dibandingkan dengan perlakuan lainnya. Menurut Anggraheni et al., (2017) pengaplikasian konsentrasi pupuk hayati secara terpisah dengan konsentrasi rendah akan meningkatkan hasil parameter bobot segar buah pertanaman juga jumlah buah panen tanaman cabai besar (C. annum L.)

\section{METODE}

Penelitian dilaksanakan pada bulan November 2019 sampai bulan Februari 2020. Berlokasi di Kota Bengkulu, Kabupaten Bengkulu Tengah, Kabupaten Kepahiang dan Kabupaten Rejang Lebong. Survei ketersediaan hayati menggunakan metode purposive sampling, yaitu dengan mempelajari peta Kota/Kabupaten, kemudian diambil sampel Kecamatan yang berada di pinggir jalan raya secara random.
A. Kota Bengkulu

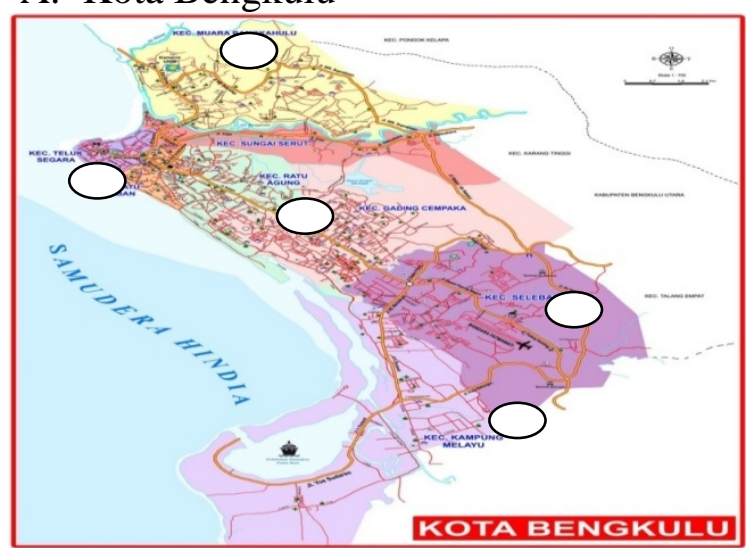

Gambar 1. Peta Kota Bengkulu (Sumber: peta-kotablogspot.com)

Jumlah kecamatan 8 :

a. Muara Bangkahulu

b. Teluk Segara

c. Ratu samban

d. Selebar

e. Kampung Melayu

f. Sungai serut

g. Ratu samban

h. Gading cempaka

Kecamatan yang di survey (tanda $\bigcirc$ ) :
a. Muara Bangkhulu
b. Teluk Segara
c. Ratu samban
d. Selebar
e. Kampung Melayu

B. Kabupaten Bengkulu Tengah

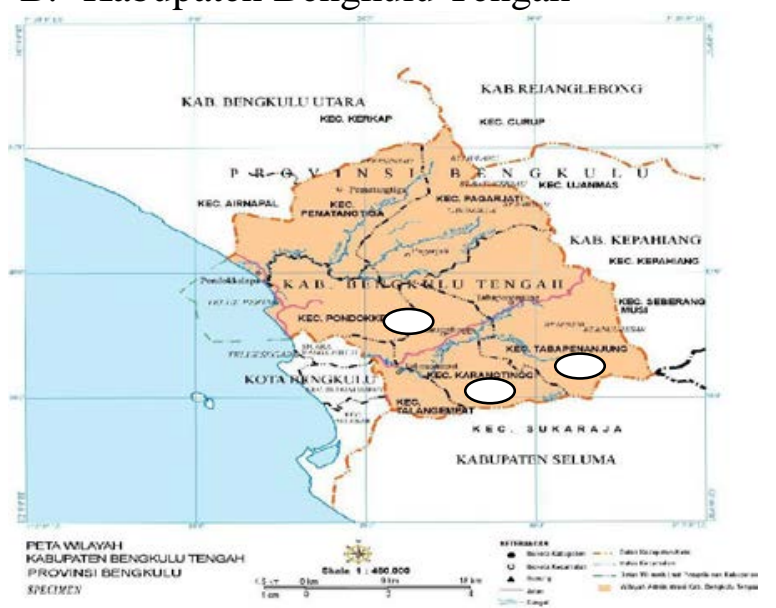

Gambar 2. Peta Kabupaten Bengkulu Tengah (Sumber: ngada.org) 
Jumlah Kecamatan Bengkulu Tengah 10 :
a. Karang Tinggi
b. Pondok Kelapa
c. Talang Empat
d. Bang Haji
e. Merigi kelindang
f. Merigi sakti
g. Pagar jati
h. Pondok kubang
i. Pematang tiga
j. Taba penanjung

Kecamatan yang di survey (tanda $\bigcirc$ ) :
a. Karang Tinggi
b. Pondok Kelapa
c. Talang Empat

C. Kabupaten Kepahiang

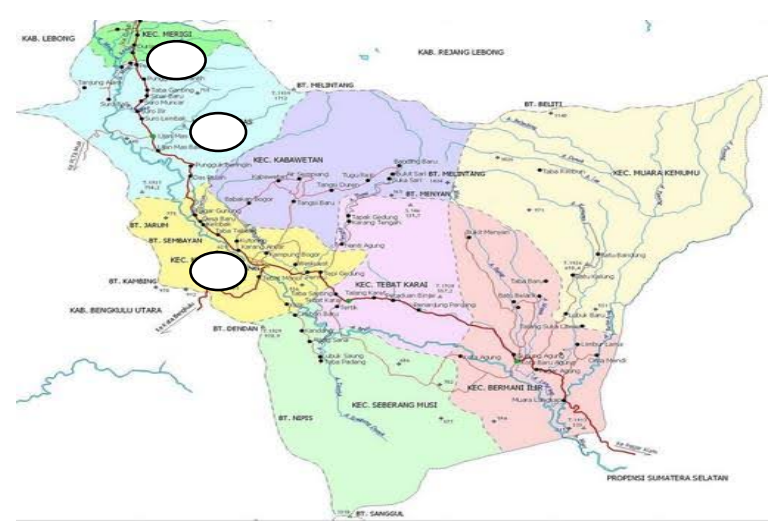

Gambar 3. Peta Kabupaten Kepahiang (Sumber: dpmptsp.bengkuluprov.go.id)

D. Kabupaten Rejang Lebong

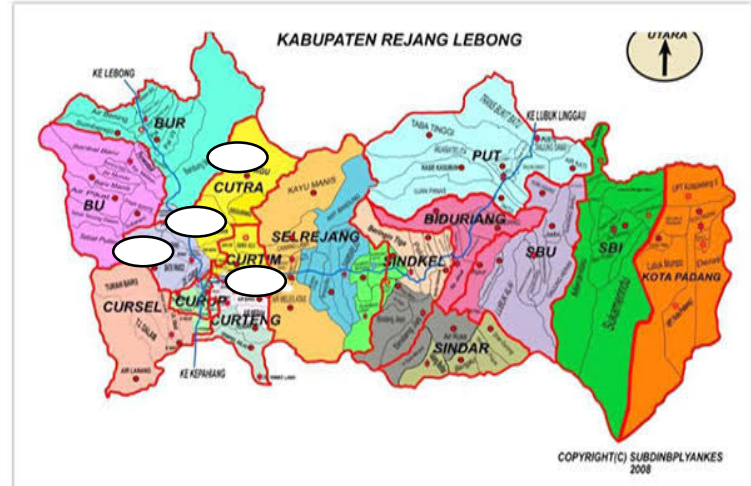

Gambar 4. Peta Kabupaten Rejang Lebong (Sumber: peta yurisdiksi pa-curup.go.id)

Jumlah kecamatan 15 :
a. Curup
b. Curup Selatan
c. Curup Tengah
d. Curup Utara
e. Bermani Ulu
f. Bermani Ulu Raya
g. Binduriang
h. Curup Timur
i. Kota Padang
j. $\quad$ Padang Ulak Tanding
k. Selupu Rejang
l. Sindang Beliti Ulu
m. Sindang Beliti Ilir
n. Sindang Dataran
o. Sindang Kelingi

Jumlah kecamatan 8 :
a. Kepahiang
b. Merigi
c. Hujan Mas
d. Bermani ilir
e. Kabawetan
f. Muara kamumu
g. Seberang musi
h. Tebat karai

Kecamatan yang di survey (tanda $\bigcirc$ ) :
a. Kepahiang
b. Merigi
c. Hujan Mas

Kecamatan yang di survey (tanda 0 ) :
a. Curup
b. Curup Selatan
c. Curup Tengah
d. Curup Utara

Ada beberapa pengamatan fisik pestisida hayati yaitu: merk dagang, kandungan/bahan aktif, fungsi kandungan/bahan aktif pada pestisida hayati. tanaman sasaran, nama perusahaan yang menerbitkan pestisida hayati, bentuk dan warna. 


\section{HASIL DAN PEMBAHASAN}

Dari hasil survey didapat hanya empat toko yang menyediakan produk dengan bahan aktif mikroorganisme di tiga Kabupaten dan empat Kecamatan, yaitu Kabupaten Bengkulu Tengah (Kecamatan Talang Empat: Futricho), Kabupaten Kepahiang (Kecamatan Kepahiang: Bionsekta, Kecamatan Merigi: Pembenah
Tanah Hayati TAYU) dan Kabupaten Rejang Lebong (Kecamatan Curup Tengah: Organic Soil Treatment (OST) Green Botane). Pestisida hayati tidak tersedia di Kota Bengkulu, salah satu penyebabnya petani belum mengerti cara mengaplikasikan pada tanaman sehingga lebih memilih pestisida kimia.

Tabel 1. Ketersediaan pestisida hayati

\begin{tabular}{|c|c|c|}
\hline (Bengkulu Tengah) & Jl. Raya Nakau & Futricho Biopestisida \\
\hline (Kepahiang) & Jl. Santoso Pasar KPH & Bionsekta \\
\hline - Kepahiang & का & Pupuk Hayati \\
\hline (Kepahiang) & Jl. Lintas Curup Kepahiang & Pembenahan Tanah Hayati (TAYU) \\
\hline $\begin{array}{l}\text { (Rejang Lebong) } \\
\text { - Curup Tengah }\end{array}$ & $\begin{array}{l}\text { Jl. Diponogoro Pasar Curup } \\
\text { Atas }\end{array}$ & $\begin{array}{l}\text { Organic Soil Treatment (OST) Green } \\
\text { Botane }\end{array}$ \\
\hline
\end{tabular}

Pestisida hayati yang diperoleh dari survey memiliki bentuk seperti tepung, cair dan butiran serta berwarna abu-abu, merah bata, coklat dan hitam. Futricho berbentuk tepung dan berwarna abu-abu mampu mengendalikan jamur busuk akar di tanaman kelapa sawit, jamur akar putih di karet dan jamur Fitopatogen (organisme yang dapat memasukkan penyakit pada inang) pada tanaman hortikultura. Bionsekta berbentuk tepung dan berwarna merah bara yang bisa mengikat nitrogen bebas sehingga mampu menambah laju pertumbuhan tanaman serta bisa mengurangi serangan penyakit tular tanah maupun menstimulasi perkembangan akar tanaman.

Pembenahan Tanah Hayati (TAYU) adalah berbentuk cair dan berwarna coklat serta baunya sedikit menyengat. Organic Soil Treatment (OST) Green Botane berbentuk butiran dan berwarna hitam akan bermanfaat untuk menaikan kesuburan tanah serta kondisi perakaran tanaman. 
Tabel 2. Pengamatan fisik pestisida hayati

\begin{tabular}{|c|c|c|c|c|c|c|c|}
\hline \multirow[t]{2}{*}{ Merk/Gol } & \multicolumn{2}{|c|}{ Sifat Fisik } & \multirow{2}{*}{\multicolumn{2}{|c|}{ Bahan Aktif }} & \multirow[t]{2}{*}{ Fungsi } & \multirow{2}{*}{$\begin{array}{l}\text { Tanaman } \\
\text { yang } \\
\text { diaplikasikan }\end{array}$} & \multirow{2}{*}{$\begin{array}{l}\text { Perusahaan } \\
\text { yang } \\
\text { Memproduksi }\end{array}$} \\
\hline & Bentuk & Warna & & & & & \\
\hline $\begin{array}{l}\text { Futricho } \\
\text { Biopestisida }\end{array}$ & Tepung & $\begin{array}{c}\text { Abu- } \\
\text { abu }\end{array}$ & & $\begin{array}{l}\text { Trichoderma } \\
\text { koningi } \\
\text { Trichoderma } \\
\text { harizanum }\end{array}$ & $\begin{array}{l}\text { Mengendalika } \\
\text { n jamur busuk } \\
\text { akar, jamur } \\
\text { akar putih dan } \\
\text { phytopatogen }\end{array}$ & $\begin{array}{l}\text { Kelapa sawit, } \\
\text { kentang, } \\
\text { kakao, karet, } \\
\text { tomat }\end{array}$ & $\begin{array}{l}\text { PT. Anugerah } \\
\text { Mustika Ostindo } \\
\text { Jakarta }\end{array}$ \\
\hline $\begin{array}{l}\text { Bionsekta } \\
\text { Pupuk } \\
\text { Hayati }\end{array}$ & Tepung & $\begin{array}{l}\text { Merah } \\
\text { bata }\end{array}$ & $\begin{array}{l}1 . \\
2 . \\
3 .\end{array}$ & $\begin{array}{l}\text { Azospirillum sp } \\
\text { Rhizobium sp } \\
\text { Pseudomonas sp }\end{array}$ & $\begin{array}{l}\text { Mengikat } \\
\text { nitrogen } \\
\text { bebas, } \\
\text { mengubah } \\
\text { fosfat tanah } \\
\text { menjadi } \\
\text { tersedia, } \\
\text { mengurangi } \\
\text { serangan tular } \\
\text { penyakit tan } \\
\text { tanah de dan } \\
\text { mentimulasi } \\
\text { perkembangan } \\
\text { akar tanaman }\end{array}$ & $\begin{array}{l}\text { Kedelai, } \\
\text { kacang tanah, } \\
\text { kacang hijau } \\
\text { dan buncis }\end{array}$ & $\begin{array}{l}\text { PT. PRIMA } \\
\text { AGRO TECH } \\
\text { Bojong Larang } \\
\text { No. 9A, Raya, } \\
\text { Tanggerang } \\
\text { 15115. } \\
\text { Indonesia }\end{array}$ \\
\hline $\begin{array}{l}\text { Pembenahan } \\
\text { Tanah } \\
\text { Hayati } \\
\text { (TAYU) }\end{array}$ & Cair & Coklat & $\begin{array}{l}1 . \\
2 . \\
3 .\end{array}$ & $\begin{array}{l}\text { Pseudomonas } \\
\text { fluorescent } \\
\text { Bulkhoderia } \\
\text { vietnamiensis } \\
\text { Trichoderma } \\
\text { polysporum }\end{array}$ & $\begin{array}{l}\text { Pembentukan } \\
\text { mikroorganis } \\
\text { me tanah, } \\
\text { mengoptimalk } \\
\text { an penyerapan } \\
\text { unsure hara } \\
\text { dan mikro } \\
\text { bagi tanaman, } \\
\text { meningkatkan } \\
\text { ketahanan } \\
\text { tanaman } \\
\text { terhadap } \\
\text { penyakit tular } \\
\text { tanah, }\end{array}$ & $\begin{array}{l}\text { Cabai, tomat } \\
\text { padi dan } \\
\text { semangka }\end{array}$ & $\begin{array}{l}\text { UD. } \quad \text { TRI } \\
\text { PUTRA AGRO } \\
\text { INDONESIA }\end{array}$ \\
\hline $\begin{array}{l}\text { Organic Soil } \\
\text { Treatment } \\
\text { (OST) } \\
\text { Green } \\
\text { Botane }\end{array}$ & Butiran & Hitam & $\begin{array}{l}1 . \\
2 . \\
3 . \\
4 . \\
5 . \\
6 .\end{array}$ & $\begin{array}{l}\text { Azobacter sp } \\
\text { Aspergillus sp } \\
\text { Bacillus sp } \\
\text { Trichoderma sp } \\
\text { Pseudomonas sp } \\
\text { Humic Acid + } \\
\text { Fulyic acid }\end{array}$ & $\begin{array}{l}\text { Meningkatkan } \\
\text { kesuburan } \\
\text { tanah dan } \\
\text { kondisi } \\
\text { perakaran } \\
\text { tanaman, } \\
\text { meningkatkan } \\
\text { kondisi fisik } \\
\text { dan biologi } \\
\text { serta kimia } \\
\text { tanah, } \\
\text { meningkatkan } \\
\text { agredasi tanah, }\end{array}$ & $\begin{array}{l}\text { Cabai, padi, } \\
\text { tomat, kelapa } \\
\text { sawit, kakao } \\
\text { dan karet }\end{array}$ & $\begin{array}{l}\text { PT. GODANG } \\
\text { TUA JAYA } \\
\text { Jakarta- } \\
\text { Indonesia }\end{array}$ \\
\hline
\end{tabular}


Dari Brosur Futricho, cara kerja Futricho sebagai kompetitor dan bahan organik yang mampu menghancurkan miselium, melilit miselium (miko-parasitik) diikuti dengan mengeluarkan enzim pendegradasi patogen. Merangsang tanaman untuk menghasilkan asam silasilat sebagai mekanisme pertahanan dari tanaman. selain itu cara kerja Futricho adalah memacu pertumbuhan rhizofungus yang dapat membantu tanaman dalam penyerapan unsur hara sehingga turut membantu pertumbuhan tanaman. Futricho diaplikasikan dengan metode tabur pada permukaan tanah dan tabur pada lubang tanam.

Kandungan Futricho adalah Trichoderma sp yang merupakan mikroorganisme tanah bersifat saprofit yang secara alami menyerang cendawan patogen dan bersifat menguntungkan bagi tanaman. Spesies Trichoderma sp yang berperan sebagai organisme pengurai serta berfungsi sebagai agen hayati bekerja berdasarkan mekanisme antagonis (Wahyuno et al., 2009). Purwantisari (2009), mengemukakan Trichoderma sp. dapat menyerang juga mengambil nutrisi dari cendawan lain. Aktivitas Trichoderma sp. sebagai mikoparasit sehingga dapat menekan patogen tular tanah (Sudantha et al., 2011).

Dari Label, bionsekta berbentuk tepung dengan cara aplikasinya adalah dosis 1 sachet Bionsekta untuk $10 \mathrm{~kg}$ benih. $10 \mathrm{~kg}$ benih dibasahi dengan air, kemudian diaduk rata selama 2-3 menit pastikan Bionsekta melekat dengan sempurna sehingga benih siap ditanam.

Dari Label, Pembenahan Tanah Hayati (TAYU) adalah berbentuk cair dan berfungsi untuk pembentukkan mikroorganisme tanah, mengoptimalkan penyerapan unsur hara makro bagi tanaman. Sanggup menaikan ketahanan tumbuhan terhadap penyakit tular tanah, memacu perkembangan tumbuhan serta tingkatkan afisiensi pengguna pupuk anorganik sebesar 25-35 \% serta bioremediasi, dosis penggunaan tayu adalah 3 liter / hektar / musim.

Green Botane bisa menaikkan efisiensi pemupukan, sebab kelima mikroba yang tercantum dalam pupuk semacam Azobacter sp., Azospirillium sp., Aspirgilus sp., Basillus sp., serta Trichoderma sp. bisa menghasilkan asamasam organik lemah yang bisa merombak serta meningkatkan kelarutan hara dalam tanah ( Khudori, 2006).

Pengendalian yang memakai pemanfaatan agen biologi merupakan bagian dari pengelolaan hama serta penyakit secara terpadu yang sudah disarankan selaku pemecahan jangka panjang yang sangat baik ( Bateman, 2002). Berdasarkan henelitian Supriadi (2013), kompatibilitas jenis pestisida dapat dikelola serta digunakan secara optimal. Mekanisme secara sinergisme atau antagonisme terlebih dahulu perlu dipahami, perusahaan pestisida diharapkan mampu memberikan informasi yang bersifat sinergisme, serta pemerintah diharapkan dapat meningkatkan pengawasan serta penyuluhan pestisida kepada pengguna.

Pestisida kimia bisa mencemari lingkungan karena bersifat beracun bila digunakan secara berlebihan. Penggunaan pestisida yang bersifat kimia kurang efisien karena tidak tepat sasaran yang membuat sebagian terbuang sia-sia di lingkungan dan berubah menjadi limbah yang bersifat berbahaya dan berdampak langsung pada lingkungan sekitar dan manusia (Wilkinson, 1988). Berdasarkan Suwahyono (2009), pengguna pestisida sentetik akan memberikan pengaruh serta dapat menggangu keselamatan baik untuk hayati, keseimbangan ekosistem dan juga bagi manusia itu sendiri. Oleh sebab itu, untuk mencegah hal-hal tersebut, telah dianjurkan pengendalian hayati yang lebih ramah lingkungan.

\section{PENUTUP}

Di Provinsi Bengkulu petani belum banyak menggunakan pestisida hayati karena kurangnya pengetahuan untuk diaplikasikan pada tanaman, sehingga hanya beberapa tokoh saja yang menjual pestisida hayati. 


\section{DAFTAR PUSTAKA}

Anggraheni, W., Nurul, A., \& Suwasono H. (2017). Pengaruh Konsentrasi serta Frekuensi Pemberian Pupuk Hayati terhadap Pertumbuhan Cabai Besar (Capsicum annum L.). Jawa Timur, Indonesia. Jurnal Produksi Tanaman, 5(1): 84-91.

Antonius, S., \& Agustiyani, D. (2011). Pengaruh Pupuk Organic Hayati Yang Mengandung Mikroba Bermanfaat Terhadap Pertumbuhan Dan Hasil Panen Tanaman Semangka Serta Sifat Biokimia Tanah Pada Percobaan Lapang di Malinau Kaltim. Jurnal Berkala Penelitian Hayati, Vol. 16: 203-206.

Bateman, R. (2002). Best-bet Solution for Cocoa Disease. Gro-Cocoa Newsletter 1:4-5.

Khudori. (2006). Teknologi Pemupukan Hayati. Republika. Jakarta.

Purwantisari, S., \& Astuti R.B. (2009). Uji Antagonisme Jamur Patogen Fhitophtora infestans Penyebab Penyakit Busuk Daun dan Umbi Tanaman Kentang dengan Menggunakan Trichoderma spp. Isolat Lokal.

Sudantha, I. M., Kesratarta, I., \& Sudana. (2011). Uji Antagonis Beberapa Jenis Jamur Saprofit Terhadap Fusarium oxysporum sp. Cubense Penyebab Penyakit Layu pada Tanaman Pisang Serta Potensinya Sebagai Agens Pengurai Serasah. Jurnal Agroteksos, 21(2): 2-3.

Supriadi. (2013). Optimasi Pemanfaatan Beragam Jenis Pestisida Untuk Mengendalikan Hama dan Penyakit Tanaman. Jurnal Litbang Pert, 32(1): 1-9.

Suwahyono, U. (2009). Biopestisida. PT. Niaga Swadaya. Jakarta.

Wahyuno, D., Manohara, D., \& Mulya, K. (2009). Peranan Bahan Organik Pada Pertumbuhan dan Daya Antagonisme Trichoderma harzianum dan Pengaruhnya Terhadap Phytophtora capsici pada
Tanaman Lada. Jurnal Fitopatologi Indonesia, 7: 76-82.

Wilkinson, C.F. (1988). Introduction and Overview, The Effects of Pesticides on Human Health. Princeton Scientific Publishing Co. Inc. Princeton, pp. 5-3. 